\title{
PROTEIN, LIPID AND ISOFLAVONE CONTENTS OF FOOD-TYPE SOYBEAN LINES AT TWO SOWING DATES
}

\author{
TEORES DE PROTEÍNA, ÓLEO E ISOFLAVONAS DE LINHAGENS DE SOJA \\ TIPO ALIMENTO EM DUAS ÉPOCAS DE SEMEADURA
}

\author{
Gustavo Henrique FREIRIA ${ }^{\text {; }}$ Leandro Simões Azeredo GONÇALVES²; \\ Wilmar Ferreira LIMA'; José Marcos Gontijo MANDARINO ${ }^{4}$; \\ Renata Rodrigues ROBAINA ${ }^{5}$; Josemeyre Bonifácio da SILVA ${ }^{6}$; \\ Cássio Egídio Cavenaghi PRETE ${ }^{2}$
}

1. Mestre em Agronomia, Universidade Estadual de Londrina - UEL, Londrina, PR, Brasil; 2. Professor, Doutor, Departamento de Agronomia, Universidade Estadual de Londrina - UEL, Londrina, PR, Brasil; 3. Pesquisador, Doutor, Instituto Agronômico do Paraná - IAPAR, Londrina, PR, Brasil; 4. Pesquisador, Mestre, Empresa Brasileira de Pesquisa Agropecuária, Centro Nacional de Pesquisa de Soja - EMBRAPA/Soja, Londrina, PR, Brasil; 5. Doutora em Produção Vegetal, Universidade Estadual do Norte Fluminense Darcy Ribeiro - UENF, Campos dos Goytacazes, RJ, Brasil; 6. Professora, Doutora, Departamento de Bioquímica e Biotecnologia, Universidade Estadual de Londrina - UEL, Londrina, PR, Brasil

\begin{abstract}
Few works have reported the relationship among genotype, temperature, rainfall and the chemical compounds of soybean. Therefore, the aim of this study was to investigate the interaction effect between soybean food-type inbred lines sowed in two different dates and the contents of protein, oil and isoflavones. Eight lines with null lipoxygenase seeds classified as food-type soybean were sowed in October 7 (early sowing) and October 29 (late sowing) at 2013/2014 crop year. The oil, protein and isoflavones contents were determined and the data were analyzed by variance analysis (ANOVA), principal component analysis (PCA) and UPGMA hierarchical. The genetic variability, sowing date and interactions between inbred lines and sowing date showed differences for all characteristics, except for oil content that did not showed a significant effect to the interaction. The greater participation of complex interaction was attributed to protein content with $87.82 \%$. According to PCA and UPGMA results, the food-type soybean lines were separated into three groups and were consistent in both sowing dates. The UEL 131 and UEL 153 lines showed the highest isoflavones content for the two sowing dates, indicating these genotypes as promising for breeding programs.
\end{abstract}

KEYWORDS: Glycine max. Null lipoxygenase genotypes. Genetic variability. Chemical compounds. Functional foods. Principal components analysis

\section{INTRODUCTION}

Soybean is a functional food (USFDA, 1999) due to its high protein content and balanced amino acid composition that can replace meat and dairy proteins in industrial food products (DAY, 2013). In addition to a high protein and oil content, soybean grains contain isoflavones.

Isoflavones are phenolic compounds that have been investigated for their human health benefits associated with the risk reduction of cancer, cardiovascular disease, and bone loss and the relief of menopause symptoms in women (LIU et al., 2012; MA et al., 2010). Moreover, isoflavones have been associated to defense factors against plant pests, in promoting nodulation by rhizobia and in changing or adjusting the microorganisms found around plant roots (WANG et al., 2015).

Soybean isoflavones are classified into four classes according to their chemical structures: aglycones (daidzein, glycitein and genistein), $\beta$ glycosides (daidzin, glycitin and genistin), 6"-Oacetylglycosides (acetyldaidzin, acetyglycitin and acetylgenistin) and 6"-O-malonylglycosides (malonyldaidzin, malonylglycitin and malonygenistin) (LIU, 1999). Among them, daidzein, genistein and glycitein are the major bioactive components in human nutrition (WANG et al., 2015).

Despite the benefits of soy consumption, currently only approximately $2-3 \%$ of the worldwide soybean production is used as human food. The greatest amount is used for animal feed (JOHNSON et al., 2008). The reasons for this are numerous, but it is probably because of its undesirable flavor. The traits of soybean flavor can be improved by using food-type soybean cultivars with null lipoxygenase enzymes (SILVA et al., 2012).

Different genotypes and climate conditions, mainly during the grain-filling stage, result in a wide variation in the protein, oil and isoflavone contents (YU et al., 2016). High temperatures during the grain-filling stage increase the oil content and influence the amino acid composition by increasing the methionine level, which is desirable for human nutrition (BARROS; 
Protein, lipid and isoflavone...

SEDIYAMA, 2009). On the other hand, high temperatures during the pod-filling stage decrease the isoflavone content (CARRÃO-PANIZZI et al., 2003; ZHANG et al., 2014; FREIRIA et al., 2016). Hoeck et al. (2000) showed that the genotype, genotype by year, genotype by location, and genotype by year by location interactions were all significant for total and individual isoflavone concentrations. Laurenz et al. (2017) assessed the isoflavone (genistein and daidzen) content in different locations and various field applied agricultural management input systems, observed that isoflavone concentrations exhibit a location specific response, and the temporal variability between years appears to influence changes in isoflavone concentrations more than in location.

The effect of genotypes and sowing dates (G X SD) and their interaction are also one of the biggest problems for breeding programs at the selection stage or for recommending cultivars (BUENO et al., 2013). There are few reports about the effect of sowing date on the chemical composition of soybean cultivars. Al-Tawaha and Seguin (2006) working with the sowing date, row spacing, and weed effects on soybean isoflavone concentrations and some other characteristics, concluded that environmental and agronomic factors greatly impact these compounds. Freiria et al. (2016) also verified the influence of the sowing data on the chemical composition of food-type
FREIRIA, G. H. et al.

soybean genotypes. Therefore, the aim of this study was to investigate the effect of the interactions between food-type soybean lines and two sowing dates on the protein, oil and isoflavone contents.

\section{MATERIAL AND METHODS}

\section{Food-type soybean lines and environmental conditions}

Eight inbred lines (UEL 101, UEL 112, UEL 113, UEL 114, UEL 121, UEL 122, UEL 131 and UEL 153) of the breeding program of the Universidade Estadual de Londrina (UEL), Londrina, Parana state, Brazil, were evaluated in the 2013/2014 crop year. All of the null lipoxygenase seeds of the lines are classified as food-type soybean (SILVA et al., 2012). The experiment was arranged in a completely randomized block with four replications with a plot of $5 \mathrm{~m} \times 0.45 \mathrm{~m} \times 0.07 \mathrm{~m}$. The sowing dates were October 7 (early sowing) and October 29 (late sowing). The seeds were sown in the farm of the UEL Agronomy School (23 ${ }^{\circ} 20^{\prime} 23^{\prime}$ ' S, 51 ${ }^{\circ} 12^{\prime}$ 32' W, 535 m altitude), Londrina, PR, Brazil. According to the climate classification Köppen the climate is $\mathrm{Cfa}$, with an annual precipitation average ranging from 1400 to $1600 \mathrm{~mm}$. The maximum and minimum rainfall and temperatures during the experimental period are shown in Figure 1.

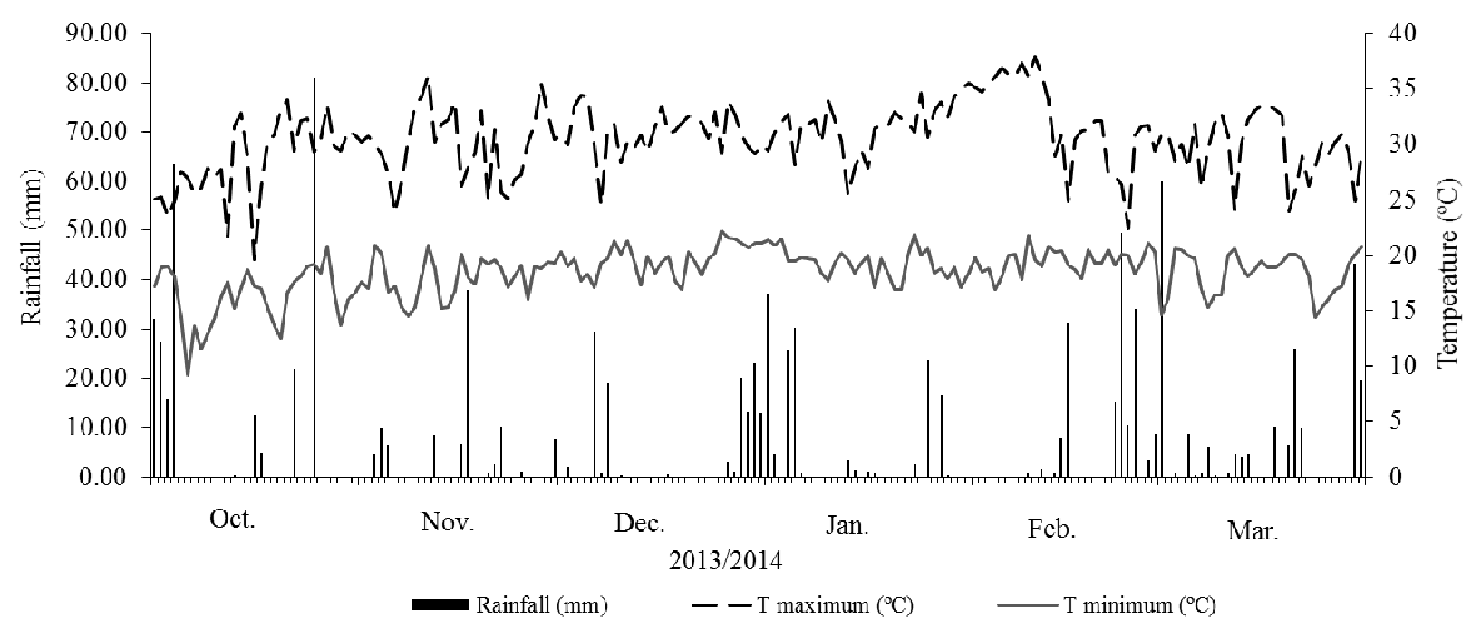

Figure 1. Rainfall, maximum and minimum temperatures observed during the experiment.

\section{Determination of protein and oil content using the NIR technique}

The oil and protein content was determined in the whole soybean grains by near-infrared spectroscopy (NIR) according to the Heil (2012) method using an Antaris ${ }^{\mathrm{TM}}$ II FT-NIR analyzer from Thermo Scientific (Madison, WI, USA). The determinations were performed in triplicate with a resolution of $2.0 \mathrm{~cm}^{-1}$ with an average of 32 scans per determination. The predictions were made by mathematical models for oil $(\mathrm{R}=0.9487)$ and crude protein $(\mathrm{R}=0.9675)$.

\section{Isoflavone analysis using the UPLC ${ }^{\circledR}$ technique}

For the determination of isoflavone content, the soybean grains were ground in a knife grinder mill (model TE 631 from Tecnal, Brazil) and defatted with hexane in a $1: 10$ ratio $(w / v)$ for 1 
Protein, lipid and isoflavone...

hour at room temperature by continuous and rotary agitation followed by vacuum filtration. The extraction was performed in duplicate with $0.5 \mathrm{~g}$ of each ground sample with $6 \mathrm{~mL}$ of $70 \%$ ethanol solution acidified with $0.001 \%$ glacial acetic acid and then stirred every $15 \mathrm{~min}$ for 1 hour at room temperature. The mixture was placed in an ultrasonic bath for $15 \mathrm{~min}$ at room temperature and then centrifuged at $21.000 \mathrm{~g}$ at $4{ }^{\circ} \mathrm{C}$ for $15 \mathrm{~min}$ (model 5804 R, Eppendorf, Hamburg, GE) and filtered using a $0.22 \mu \mathrm{m}$ Millex filter. The separation and quantification of the isoflavones were performed in duplicate according to Berhow (2002) using an Ultra-Performance Liquid Chromatography (UPLC) system. The column was a reversed-phase type (model ACQUITY-UPLC BEH C18, Waters, United States) with dimensions of $2.1 \mathrm{~mm}$ (ID) x $50 \mathrm{~mm}$ length and a particle size of $1.7 \mu \mathrm{m}$. Elution was performed in a linear binary gradient system using mobile phase A containing methanol with $0.025 \%$ trifluoroacetic acid and mobile phase B containing ultrapure deionized water with $0.025 \%$ trifluoroacetic acid. The flow rate applied was $0.35 \mathrm{~mL} \mathrm{~min}^{-1}$ at $24^{\circ} \mathrm{C}$. The gradient began with $25 \%$ eluent $\mathrm{A}$; at the 7 min gradient, the elution ratio ultimately reached $80 \% \mathrm{~A}$, and then the initial conditions were restored at $\min 8$, with a total run time of $10 \mathrm{~min}$. The detector was a photodiode array (Waters, United States) with the wavelength adjusted at 254 nm. Standard solutions for calibration curve construction (peak area of isoflavone contents) were made for each of the twelve isoflavones forms: daidzin, genistin, glycitin, malonyldaidzin, malonylgenistin, malonylglycitin, acetyldaidzin, acetylgenistin, acetylglycitin, daidzein, glycitein and genistein, which were purchased from Sigma and Fluka $\left(0.5 \mu \mathrm{g} \mathrm{mL}^{-1} ; 1 \mu \mathrm{g} \mathrm{mL}^{-1}, 2 \mu \mathrm{g} \mathrm{mL} \mathrm{m}^{-1} ; 4\right.$ $\mu \mathrm{g} \mathrm{mL}^{-1} ; 6 \mu \mathrm{g} \mathrm{mL}^{-1} ; 8 \mu \mathrm{g} \mathrm{mL}^{-1}$ e $\left.10 \mu \mathrm{g} \mathrm{mL}^{-1}\right)$. The standards were injected in triplicate to yield the corresponding chromatograms for the isoflavone forms, each with its corresponding retention time.

The peaks for each isoflavone in the samples were identified for the comparison of the retention times and the UV spectrum of the respective standard reference regions. The application was coupled in the chromatographgenerated calibration curves, and the isoflavone concentrations were calculated and expressed in $\mathrm{mg}$ for each isoflavone per $100 \mathrm{~g}$ of sample (mg isoflavone $100 \mathrm{~g}^{-1}$ ).

\section{Data Analysis}

The data for each individual characteristic evaluated were subjected to an analysis of variance (ANOVA). After verification of the homogeneity of variances using the Hartley test, performed a $8 \mathrm{x}$
FREIRIA, G. H. et al.

2 factorial design with eight inbred lines and two sowing dates. When a significant effect was found ( $\mathrm{p} \leq 0.05$ ), the means were compared using the Scott-Knott test $(\mathrm{p} \leq 0.05)$. The complex interaction among the genotype with the sowing date was analyzed using the algorithm proposed by Cruz and Castoldi (1991), in which the complex part was expressed as follows:

$$
\mathrm{C}=\sqrt{ }(1-\mathrm{r})^{3} \sqrt{ } \mathrm{Q}_{1} \mathrm{Q}_{2}
$$

where Q1 and Q2 corresponded to the mean squares of the lines in the first and second sowing date, respectively, and $\mathrm{r}$ is the correlation among the genotypes in both seasons. The eight inbred food-type soybean lines were grouped based on the genetic similarity matrix by the standardized mean Euclidean distance and using the Unweighted Pair-Group Method with Arithmetic Mean hierarchy (UPGMA). The data were also submitted to Principal Components Analysis (PCA). The statistical analyses were performed using the GENES computational application (CRUZ, 2016) and the $\mathrm{R}$ program ( $\mathrm{R}$ DEVELOPMENT CORE TEAM, 2012).

\section{RESULTS AND DISCUSSION}

According to the analysis of variance, lines (L) and sowing date (S) showed significant differences for protein, oil and total isoflavones content (Table 1). The L x S interactions, only oil content did not show significant effect. Al-Tawaha and Seguin (2006) observed that the oil, protein and isoflavone contents were influenced by sowing date and genotype. The mean values obtained for protein, oil and total isoflavone content were in accordance with data reported in the literature for soybean (SEIBEL et al., 2013; RODRIGUES et al., 2014). Dardanelli et al. (2006) reported that protein and oil can vary in an inverse relationship due to the changes in temperature during plant development. However, the temperature does not seem to be directly related to the protein content; rather, it indirectly influences it via the oil content because these two characteristics are inversely correlated.

Regarding each form of isoflavone, $\beta$ glycosides, malonylglycosides and aglycones, except glycitein, showed differences for lines, sowing date and $\mathrm{L} \times \mathrm{S}$ interactions. The genotypic variance is one of the most important parameters for quantifying the breeding potential of a population. The presence of genotypic variance among the tested averages indicates the viability of the use of selective techniques in genotypes. The interaction between genotype $\mathrm{x}$ environment becomes a complicating factor in a breeding program only when much of this interaction is 
Protein, lipid and isoflavone...

FREIRIA, G. H. et al.

considered complex, causing changes in the in selection and/or recommendations.

genotype classification and resulting in difficulty

Table 1. Mean square values and estimate of complex interaction (CI) for the protein, oil and isoflavones contents of soybean food-type lines, at two sowing dates, in 2013/2014 growing season.

\begin{tabular}{|c|c|c|c|c|c|c|}
\hline \multirow{2}{*}{ Variables } & \multicolumn{3}{|c|}{ Mean Square } & \multirow[b]{2}{*}{ Residue } & \multirow[b]{2}{*}{ Mean } & \multirow{2}{*}{$\mathrm{CV}(\%)$} \\
\hline & Lines (L) & Sowing date $(\mathrm{S})$ & $\mathrm{L} \times \mathrm{S}$ & & & \\
\hline Protein & $4.45^{* *}$ & $118.76^{* *}$ & $3.74 *$ & 1.39 & 38.61 & 3.05 \\
\hline Oil & $4.41 * *$ & $31.14 * *$ & $0.81^{\mathrm{NS}}$ & 0.55 & 20.77 & 3.66 \\
\hline \multirow[t]{2}{*}{ Total isoflavones } & $24797.91 * *$ & $41237.42 * *$ & $2240.24 * *$ & 37.62 & 197.96 & 3.10 \\
\hline & & $\beta$-glycosides & & & & \\
\hline Daidzin & $787.01 * *$ & $277.97 * *$ & $40.68 * *$ & 0.65 & 23.69 & 3.41 \\
\hline Glicitin & $11.98 * *$ & $22.49 * *$ & $2.45 * *$ & 0.53 & 3.52 & 20.76 \\
\hline \multirow[t]{2}{*}{ Genistin } & $724.93 * *$ & $370.80 * *$ & $73.50 * *$ & 0.68 & 39.65 & 2.08 \\
\hline & & Malonyl & & & & \\
\hline M-daidzin & $2129.27 * *$ & $3742.38 * *$ & $115.56^{* *}$ & 2.03 & 43.77 & 3.25 \\
\hline M-glycitin & $90.27 * *$ & $108.92 * *$ & $22.03 * *$ & 3.26 & 8.02 & 22.50 \\
\hline \multirow[t]{2}{*}{ M-genistin } & $4074.13 * *$ & $8270.77 * *$ & $353.40 * *$ & 2.40 & 74.61 & 2.08 \\
\hline & & Aglycones & & & & \\
\hline Daidzein & $3.15 * *$ & $0.31 * *$ & $1.26^{* *}$ & 0.01 & 1.98 & 5.18 \\
\hline Glycitein & $0.169 * *$ & $0.001^{\mathrm{NS}}$ & $0.021 * *$ & 0.001 & 0.62 & 3.79 \\
\hline Genistein & $1.34 * *$ & $0.47 * *$ & $1.15^{* *}$ & 0.003 & 2.09 & 2.52 \\
\hline
\end{tabular}

** and *: significant at 1 and $5 \%$, respectively, by $\mathrm{F}$ test; ${ }^{\mathrm{NS}}$ : no significant

The percentage of complex interaction to lines $\mathrm{x}$ sowing date according to Cruz and Castoldi (1991) is shown in the Figure 2. The greater participation of complex interaction was attributed to protein content with $87.82 \%$. The complex part of the genotype $\mathrm{x}$ environment interaction is given by the lack of correlation among phenotype, genotype and environmental deviations (CARGIN et al., 2006). The isoflavone content (34.84\%) showed less environmental impact on the classification of the inbred lines and the sowing dates. However, when the different isoflavone forms were analyzed, a greater participation of the complex interaction for malonylglycitin, daidzein and genistein was found. A high percentage of complex interaction makes it necessary to search for measures to reduce the effects of the genotype $\mathrm{x}$ environment interaction, detailing the responses of each genotype on environmental variations (SILVA et al., 2013). 


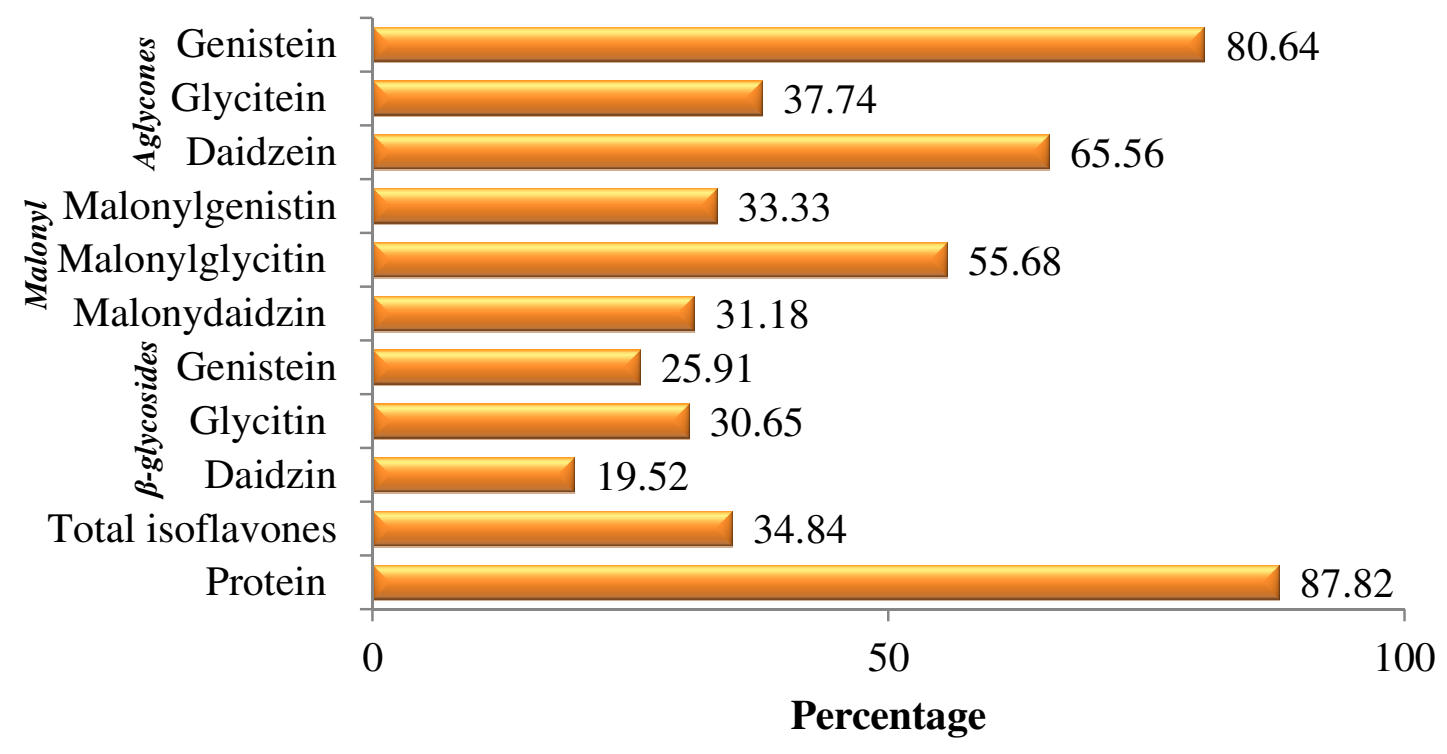

Figure 2. Estimation of the complex interaction for the chemical composition of eight food-type soybean inbred lines.

The average values of the oil, protein and isoflavone contents are shown in Table 2. Overall, the protein content was greater with the early sowing date except for the UEL 131 line. In the early sowing date, we can observe two groups of lines, a group with an average level equal to 40.72 \% (UEL 101, UEL 112, UEL 121, UEL 122 and UEL 153) and a group with an average level equal to $38.73 \%$ (UEL 113, UEL 114 and UEL 131). There were no differences in the late sowing date among the lines. For the oil content, the highest values were for the UEL 114 and UEL 121 lines (21.93 and 21.37, respectively).

Considering the total isoflavones, large values for isoflavone contents were obtained for the late sowing date. Individual isoflavone forms responded differently to the genetic background of the lines and to the sowing dates. Overall, the highest content of $\beta$-glycosides (daidzin, glycitin and genistein), malonylglycosides (malonydaidzin, malonylglycitin and malonylgenistin) and aglycones (daidzein, glycitein and genistein) were obtained in the late sowing date, with an exception for the malonylglycitin and glycitin forms.

For the late sowing date high contents of total isoflavones were observed for all lines except UEL 131. Some other studies describe the influence of climatic conditions on the isoflavone contents during the grain-filling stage (MORRISON et al., 2010; KIM et al. 2012). Freiria et al. (2016) also observed differences between sowing dates for isoflavones concentration in food-type soybean lines. In this study, the higher isoflavone concentrations of the later sowing date could be a result of the lower temperatures and greater precipitation during the development and seed-filling stage.

The UEL 131 and UEL 153 food-type soybean inbred lines showed the highest content of total isoflavones for the two sowing dates, indicating these genotypes as promising for breeding programs. Regarding each form of isoflavone, these inbred lines obtained the highest values for $\beta$-glycosides (daidzin and genistein), malonylglycosides (daidzin and genistin) and aglycones (glycitein) (Table 2). For acetylgenistein, these lines obtained the highest content only for early sowing, while in the late sowing the highest content was obtained by the UEL 121. For glycitin and malonylglycitin, the highest content were obtained for the UEL 112 and UEL 122 inbred lines.

In the principal component analysis (PCA), the two first principal axes explained $90.62 \%$ of the total variance of the early sowing date and $81.89 \%$ of the late sowing date (Figure 3). This values indicates that the graphical representation of the two first PCAs is appropriate for the visualization of the relationships among variables and among lines.

In the two growing dates, there is a negative correlation between protein and oil. These results are similar to those obtained by Bueno et al. (2013) and Recker et al. (2014). Positive correlation was observed between B-glycosides, malonylglycosidics and aglycones groups with total isoflavones at both sowing dates, except in the chemical forms glycitin and malonylglicitin.

According to Gutierrez-Gonzalez et al. (2010) the different forms of isoflavones share a 
Protein, lipid and isoflavone...

common pathway for their synthesis, the phenylpropanoid pathway. Thus, positive correlations among the different groups and among the groups and the total isoflavone content was already expected. However, the negative correlation between glycitin and malonylglycitin with the other isoflavones forms can be attributed to existing differentiations in the phenylpropanoid pathway (KIM et al. 2014). The absence of correlation between these two forms and the other isoflavones in the late sowing indicates the environmental participation in the establishment of metabolic pathway.

The groups identified by the cluster analysis via PCA were concordant in the two sowing date, except for UEL 101 (Figure 3). The
FREIRIA, G. H. et al.

grouping of the UEL 153 and UEL 131 inbred lines, in both sowing dates, is related to the ability of these inbred lines showed the highest isoflavones content. On the other hand, the grouping of the UEL 114, UEL 113 and UEL 112 inbred lines is related to the low accumulation of this bioflavonoid, with the exception of the glycitin and malonilglycitin forms.

The UEL 121, UEL 122 and UEL 110 lines showed variations in their relations with the chemical components with the change in the growing dates. According to Rangel et al. (2007) environmental factors may strongly contribute to the chemical composition of soybeans, independently of the genes per se, which corroborates the results found.
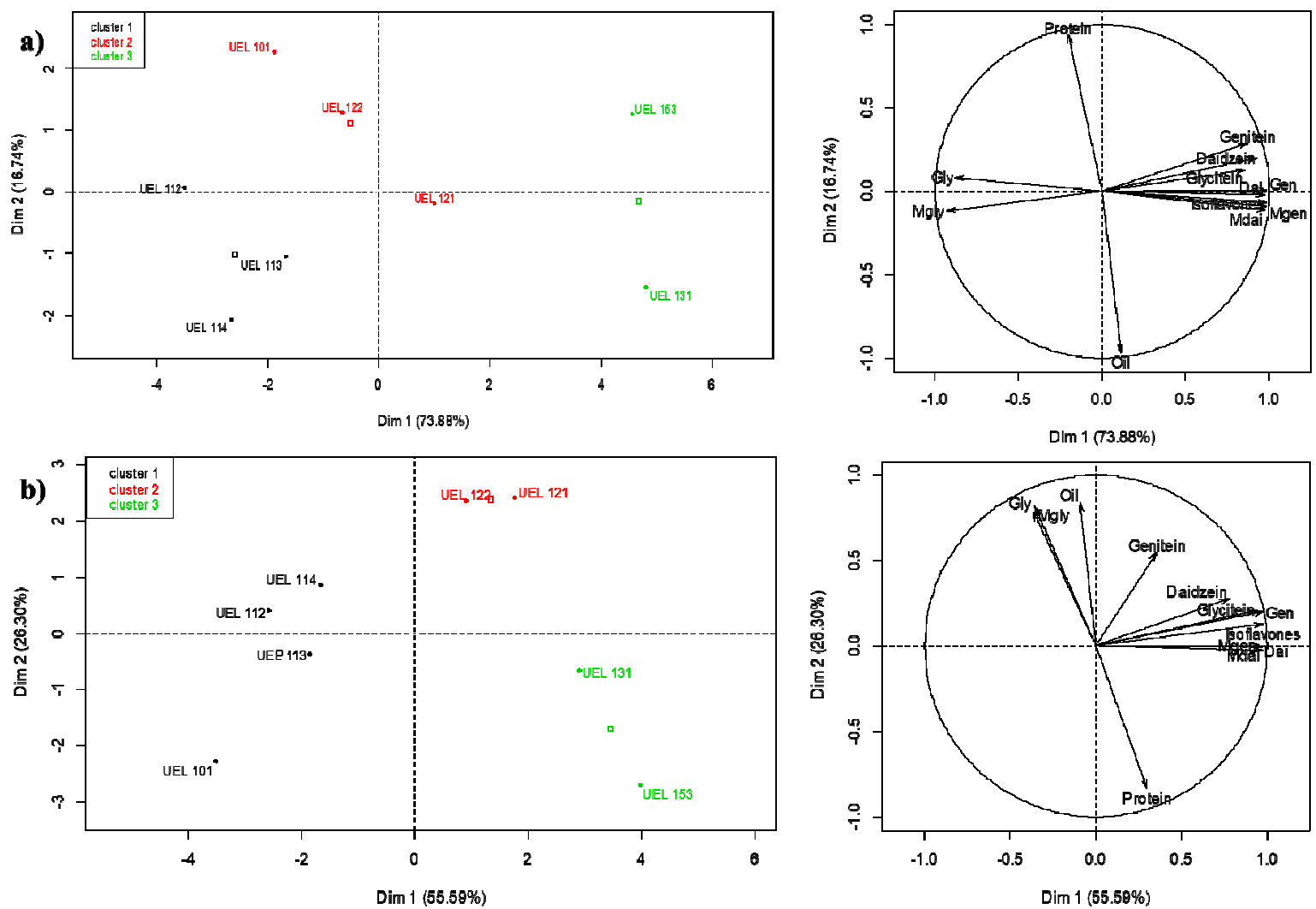

Figure 3. Principal Components Analysis (PCA) of all lines cultivated in early (a) and late (b) sowing date, respectively. 
Protein, lipid and isoflavone...

FREIRIA, G. H. et al.

Table 2. Protein, oil and isoflavones contents of soybean food-type lines at early (ES) and late sowing date (LS).

\begin{tabular}{|c|c|c|c|c|c|c|c|c|c|c|c|c|}
\hline \multirow{3}{*}{ Genotypes } & \multirow{2}{*}{\multicolumn{2}{|c|}{ Protein $(\%)$}} & \multirow{2}{*}{\multicolumn{2}{|c|}{ Oil (\%) }} & \multirow{2}{*}{\multicolumn{2}{|c|}{ 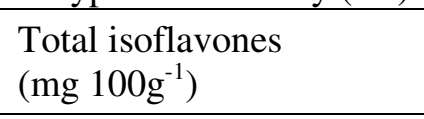 }} & \multicolumn{6}{|c|}{$\beta$-glycosides $\left(\mathrm{mg} 100 \mathrm{~g}^{-1}\right)$} \\
\hline & & & & & & & \multicolumn{2}{|c|}{ Dai } & \multicolumn{2}{|l|}{ Gly } & \multicolumn{2}{|l|}{ Gen } \\
\hline & ES & $\mathrm{LS}$ & Mean & & $\mathrm{ES}$ & $\mathrm{LS}$ & ES & LS & ES & $\mathrm{LS}$ & ES & $\mathrm{LS}$ \\
\hline UEL 101 & $41.53 \mathrm{Aa}$ & $37.49 \mathrm{Ba}$ & $19.69 \mathrm{c}$ & & $117.67 \mathrm{Bf}$ & $145.05 \mathrm{Ag}$ & $11.64 \mathrm{Ae}$ & $12.14 \mathrm{Af}$ & $3.17 \mathrm{Ab}$ & $2.85 \mathrm{Ad}$ & $28.53 \mathrm{Bf}$ & $30.12 \mathrm{Ag}$ \\
\hline UEL 112 & 39.96 Аa & $37.46 \mathrm{Ba}$ & $20.68 \mathrm{~b}$ & & $120.33 \mathrm{Bf}$ & 173.87 Af & $12.19 \mathrm{Be}$ & $19.86 \mathrm{Ae}$ & $4.49 \mathrm{Ba}$ & $5.58 \mathrm{Ab}$ & $25.57 \mathrm{Bg}$ & $34.19 \mathrm{Af}$ \\
\hline UEL 113 & $39.21 \mathrm{Ab}$ & $37.31 \mathrm{Ba}$ & $20.82 b$ & & $141.62 \mathrm{Be}$ & $187.99 \mathrm{Ae}$ & $17.93 \mathrm{Bd}$ & $23.42 \mathrm{Ad}$ & $3.38 \mathrm{Bb}$ & $4.79 \mathrm{Ac}$ & $31.86 \mathrm{Be}$ & $37.19 \mathrm{Ae}$ \\
\hline UEL 114 & $38.78 \mathrm{Ab}$ & $36.37 \mathrm{Ba}$ & $21.93 \mathrm{a}$ & & $119.01 \mathrm{Bf}$ & $206.51 \mathrm{Ad}$ & $11.73 \mathrm{Be}$ & $18.83 \mathrm{Ae}$ & $3.08 \mathrm{Bb}$ & $4.23 \mathrm{Ac}$ & $25.73 \mathrm{Bg}$ & $37.71 \mathrm{Ae}$ \\
\hline UEL 121 & $40.31 \mathrm{Aa}$ & $36.17 \mathrm{Ba}$ & $21.37 \mathrm{a}$ & & $179.53 \mathrm{Bc}$ & $248.30 \mathrm{Ac}$ & $21.30 \mathrm{Bc}$ & $29.49 \mathrm{Ac}$ & $2.09 \mathrm{Bc}$ & $4.31 \mathrm{Ac}$ & $41.00 \mathrm{Bc}$ & $49.93 \mathrm{Ab}$ \\
\hline UEL 122 & $41.37 \mathrm{Aa}$ & $36.89 \mathrm{Ba}$ & $20.71 b$ & & $166.42 \mathrm{Bd}$ & $261.67 \mathrm{Ab}$ & $20.53 \mathrm{Bc}$ & $28.60 \mathrm{Ac}$ & $3.61 \mathrm{Bb}$ & $6.76 \mathrm{Aa}$ & $38.07 \mathrm{Bd}$ & 46.82 Ad \\
\hline UEL 131 & $38.21 \mathrm{Ab}$ & $37.58 \mathrm{Aa}$ & $21.13 b$ & & $276.86 \mathrm{Aa}$ & $269.76 \mathrm{Ab}$ & $37.78 \mathrm{Ab}$ & $34.73 \mathrm{Bb}$ & $1.94 \mathrm{Ac}$ & $2.53 \mathrm{Ad}$ & $54.99 \mathrm{Aa}$ & $48.87 \mathrm{Bc}$ \\
\hline UEL 153 & $40.44 \mathrm{Aa}$ & $38.74 \mathrm{Ba}$ & $19.85 \mathrm{c}$ & & $259.15 \mathrm{Bb}$ & $293.59 \mathrm{Aa}$ & $39.78 \mathrm{Aa}$ & $39.17 \mathrm{Aa}$ & $1.68 \mathrm{Ac}$ & $1.87 \mathrm{Ad}$ & $52.20 \mathrm{Ab}$ & $51.65 \mathrm{Aa}$ \\
\hline \multirow{3}{*}{ Genótipo } & \multicolumn{6}{|c|}{ Malonylglycosidics (mg 100g ${ }^{-1}$ ) } & \multicolumn{6}{|c|}{ Aglycones (mg 100g $\left.{ }^{-1}\right)$} \\
\hline & \multicolumn{2}{|c|}{ Mdai } & \multicolumn{2}{|l|}{ Mgly } & \multicolumn{2}{|l|}{ Mgen } & \multicolumn{2}{|c|}{ Daidzein } & \multicolumn{2}{|l|}{ Glycitein } & \multicolumn{2}{|l|}{ Genitein } \\
\hline & ES & LS & $\mathrm{ES}$ & LS & $\mathrm{ES}$ & LS & $\mathrm{ES}$ & $\mathrm{LS}$ & $\mathrm{ES}$ & $\mathrm{LS}$ & $\mathrm{ES}$ & $\mathrm{LS}$ \\
\hline UEL 101 & $19.01 \mathrm{Bg}$ & $27.71 \mathrm{Ah}$ & $7.24 \mathrm{Ab}$ & $6.12 \mathrm{Ac}$ & $43.19 \mathrm{Bf}$ & $62.53 \mathrm{Ag}$ & $1.86 \mathrm{Ac}$ & $1.29 \mathrm{Be}$ & $0.49 \mathrm{Ae}$ & $0.43 \mathrm{Be}$ & $2.56 \mathrm{Ab}$ & $1.88 \mathrm{Bd}$ \\
\hline UEL 112 & $22.59 \mathrm{Bf}$ & $37.01 \mathrm{Ag}$ & $11.93 \mathrm{Aa}$ & $12.27 \mathrm{Ab}$ & $40.41 \mathrm{Bg}$ & $60.54 \mathrm{Ag}$ & $1.17 \mathrm{Be}$ & $1.91 \mathrm{Ad}$ & $0.44 \mathrm{Af}$ & $0.47 \mathrm{Ad}$ & $1.56 \mathrm{Be}$ & $2.05 \mathrm{Ac}$ \\
\hline UEL 113 & $28.87 \mathrm{Be}$ & 42.43 Af & $8.89 \mathrm{Ab}$ & $10.42 \mathrm{Ab}$ & $47.00 \mathrm{Be}$ & $65.61 \mathrm{Af}$ & $1.52 \mathrm{Bd}$ & $1.93 \mathrm{Ad}$ & $0.54 \mathrm{Ad}$ & $0.49 \mathrm{Bd}$ & $1.63 \mathrm{Be}$ & $1.71 \mathrm{Af}$ \\
\hline UEL 114 & $23.23 \mathrm{Bf}$ & $45.45 \mathrm{Ae}$ & $8.73 \mathrm{Ab}$ & $10.94 \mathrm{Ab}$ & $43.56 \mathrm{Bf}$ & $85.95 \mathrm{Ae}$ & $1.08 \mathrm{Be}$ & $1.28 \mathrm{Ae}$ & $0.40 \mathrm{Bg}$ & $0.62 \mathrm{Ac}$ & $1.47 \mathrm{Af}$ & $1.51 \mathrm{Ag}$ \\
\hline UEL 121 & $37.26 \mathrm{Bc}$ & $55.09 \mathrm{Ad}$ & $4.21 \mathrm{Bc}$ & $9.96 \mathrm{Ab}$ & $69.14 \mathrm{Bc}$ & $93.04 \mathrm{Ad}$ & $1.67 \mathrm{Bd}$ & $3.00 \mathrm{Aa}$ & $0.82 \mathrm{Aa}$ & $0.70 \mathrm{Bb}$ & $2.07 \mathrm{Bc}$ & $2.80 \mathrm{Aa}$ \\
\hline UEL 122 & $33.28 \mathrm{Bd}$ & $60.65 \mathrm{Ac}$ & $7.08 \mathrm{Bb}$ & $16.33 \mathrm{Aa}$ & $59.76 \mathrm{Bd}$ & $97.56 \mathrm{Ac}$ & $1.55 \mathrm{Bd}$ & $2.06 \mathrm{Ad}$ & $0.72 \mathrm{Ac}$ & $0.72 \mathrm{Ab}$ & $1.82 \mathrm{Bd}$ & $2.18 \mathrm{Ab}$ \\
\hline UEL 131 & $63.92 \mathrm{Ba}$ & $66.69 \mathrm{Ab}$ & $3.24 \mathrm{Ac}$ & $4.87 \mathrm{Ac}$ & $108.08 \mathrm{Aa}$ & $106.64 \mathrm{Ab}$ & $2.97 \mathrm{Ab}$ & $2.62 \mathrm{Bb}$ & $0.80 \mathrm{Aa}$ & $0.74 \mathrm{Ba}$ & $3.14 \mathrm{Aa}$ & $2.09 \mathrm{Bc}$ \\
\hline UEL 153 & $60.87 \mathrm{Bb}$ & $76.35 \mathrm{Aa}$ & $2.44 \mathrm{Ac}$ & $3.72 \mathrm{Ac}$ & $94.79 \mathrm{Bb}$ & $115.95 \mathrm{Aa}$ & $3.49 \mathrm{Aa}$ & $2.34 \mathrm{Bc}$ & $0.77 \mathrm{Ab}$ & $0.76 \mathrm{Aa}$ & $3.13 \mathrm{Aa}$ & $1.79 \mathrm{Be}$ \\
\hline
\end{tabular}


The groups formed by PCA were concordant with those obtained by the UPGMA method at both sowing dates (Figure 4). The formation of these groups is valuable information for a breeding program because cultivars which are in distant groups are considered more suitable for artificial breeding (VILLELA et al. 2014). However, different environmental conditions should be tested for genetic dissimilarity of the chemical components of soybeans due to the great influence of environmental conditions in the expression of these traits.

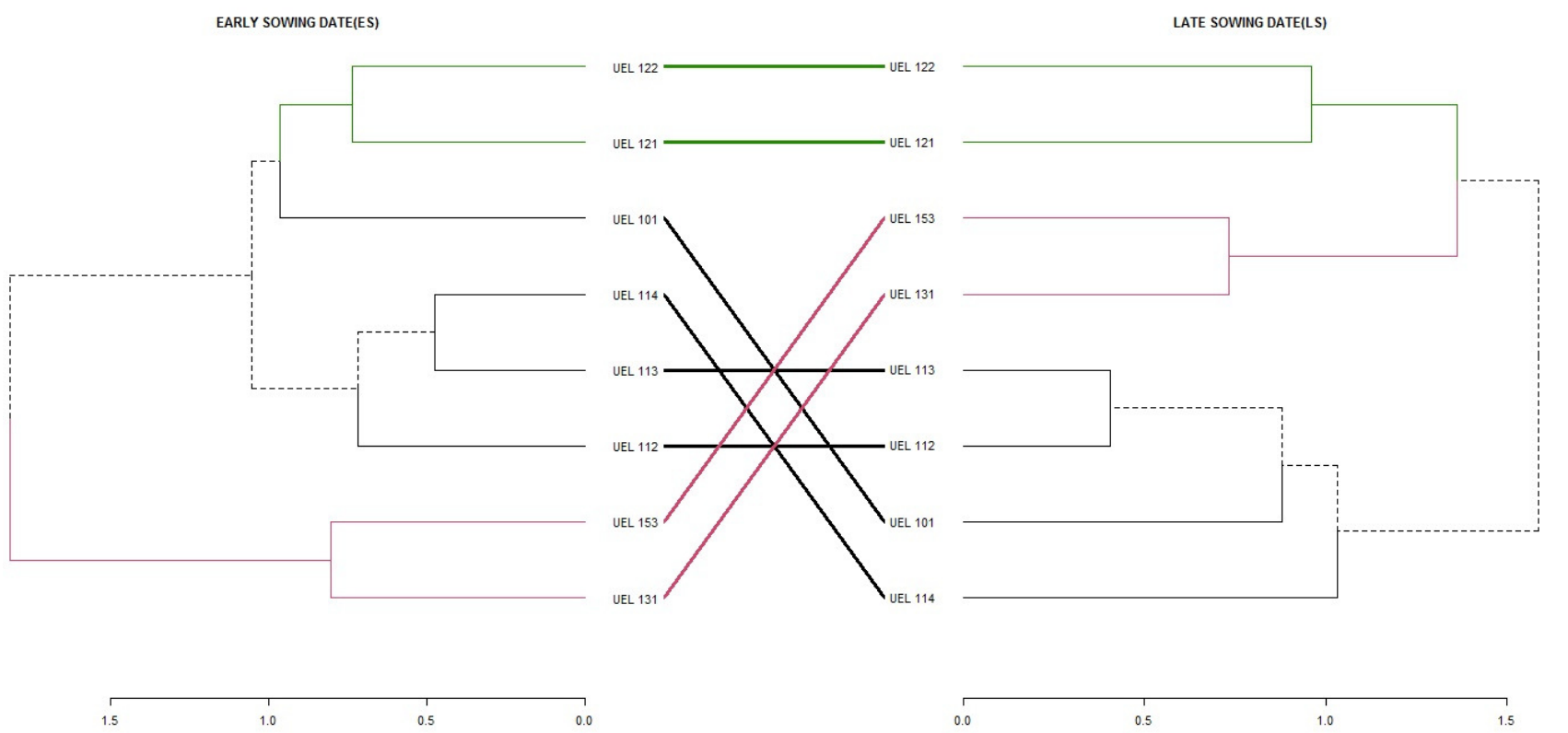

Figure 4. Dendrogram obtained by the UPGMA method representing the genetic dissimilarity among eight food-type soybean lines based on oil, protein and isoflavone contents.

\section{CONCLUSION}

The relationship among soybean food-type inbred lines, oil, protein, isoflavones contents and genetic dissimilarity are influence by the sowing dates. The UEL 131 and UEL 153 lines showed the highest isoflavones content for the two sowing dates, indicating these genotypes as promising for breeding programs.

RESUMO: Poucos trabalhos relataram a relação entre genótipo, temperatura, precipitação e os compostos químicos de grãos de soja. Portanto, o objetivo deste estudo foi investigar o efeito da interação entre linhagens de soja tipo alimento semeadas em duas épocas nos teores de proteína, óleo e isoflavonas nos grãos. Oito linhagens de soja ausentes das enzimas lipoxigenases e classificadas como tipo alimento foram semeadas em 7 de outubro (semeadura precoce) e 29 de outubro (semeadura tardia) no ano agrícola 2013/2014. Os conteúdos de óleo, proteína e isoflavonas foram determinados e os dados foram submetidos a análise de variância (ANAVA), análise de componentes principais (PCA) e UPGMA hierárquica. A variabilidade genética, a época de semeadura e as interações entre linhagens e a época de semeadura mostraram diferenças para todas as características, com exceção do teor de óleo que não apresentou efeito significativo na interação. A maior participação da interação complexa foi atribuída ao teor de proteína com $87,82 \%$. De acordo com os resultados da PCA e UPGMA, as linhagens de soja tipo alimento foram separadas em três grupos que se mantiveram com a mudança da época de semeadura. As linhagens UEL 131 e UEL 153 mostraram o maior teor de isoflavonas em ambas as épocas de semeadura, indicando que esses genótipos são promissores para programas de melhoramento.

PALAVRAS-CHAVES: Glycine max. Genótipos sem lipoxigenases. Variabilidade genética. Composição química. Alimento funcional. Analise de componentes principais 


\section{REFERENCES}

AL-TAWAHA, A. M.; SEGUIN, P. Seeding date, row spacing, and weed effects on soybean isoflavone concentrations and other seed characteristics. Canadian Journal of Plant Science, Vancouver, v. 86, n. 4, p. 1076-1087, 2006. https://doi.org/10.4141/P06-043

BARROS, H. B.; SEDIYAMA, T. Luz, umidade e temperatura. In: SEDIYAMA, T. (Ed.). Tecnologias de produção e usos da soja, Londrina: Mecenas, 2009. p. 17-27.

BERHOW, M. A. Modern analytical techniques for flavonoid determination. In: BUSLIG, B. S.; MANTHEY, J. A. (Ed.). Flavonoids in the living cell, New York: Klusher Academic, 2002, p.61-76. https://doi.org/10.1007/978-1-4757-5235-9_6

BUENO, R. D.; BORGES, L. L.; ARRUDA, K. M. A.; BHERING, L. L.; BARROSM, E. G.; MOREIRA, A. Genetic parameters and genotype $\mathrm{x}$ environment interaction for productivity, oil and protein content in soybean. African Journal of Agricultural Research, v. 8, n. 38, p. 4853-4859, 2013. http://dx.doi.org/ 10.5897/AJAR2013.6924

CARGIN, A.; SOUZA, M. A.; CARNEIRO, P. C.; SOFIATTI, V. Genotypes and environments interaction and its implication in gain with wheat selection. Pesquisa Agropecuária Brasileira, Brasília, v. 41, n. 6, p. $987-$ 993, 2006. http://dx.doi.org/10.1590/S0100-204X2006000600014

CARRÃO-PANIZZI, M. C.; SIMÃO, A. S.; KIKUCHI, A. Effects of genotypes, environments and hydrothermal treatments on the isoflavone aglycone concentration in soybean grains. Pesquisa Agropecuária Brasileira, Brasília, v. 38, n. 8, p. 897-902, 2003. http://dx.doi.org/10.1590/S0100-204X2003000800001

CRUZ, C. D.; CASTOLDI, F. L. Decomposição da interação genótipo x ambiente em partes simples e complexas. Revista Ceres, Viçosa, v. 38, n. 219, p.422-430, 1991.

CRUZ, C.D. Genes software - extended and integrated with the R, Matlab and Selegen. Acta Scientiarum. Agronomy, Maringá, v. 38, n. 4, p.547-552, 2016. http://dx.doi.org/10.4025/actasciagron.v38i4.32629

DARDANELLI, J. L.; BALZARINI, M.; MARTÍNEZ, M. J.; CUNIBERTI, M.; RESNIK, S.; RAMUNDA, S. F.; HERRERO, R.; BAIGORRI, H. Soybean maturity groups, environments, and their interaction define megaenvironments for seed composition in Argentina. Crop Science, Madison, v. 46, p. 1939-1947, 2006. http://dx.doi.org/ 10.2135/cropsci2005.12-0480

DAY, L. Proteins from land plants - Potential resources for human nutrition and food security. Trends in Food Science \& Technology, Norwich, v. 32, p. 25-42, 2013. https://doi.org/10.1016/j.tifs.2013.05.005

FREIRIA, G. H.; LIMA, W. F; LEITE, R. S.; MANDARINO, J. M. G.; SILVA, da J. B.; PRETE, C. E. C. Productivity and chemical composition of food-type soybeans sown on different dates. Acta Scientiarum Agronomy, Maringá, v. 38, n. 3, p. 371-377, 2016. http://dx.doi.org/10.4025/actasciagron.v38i3.28632

GUTIERREZ-GONZALES, J. J.; WU, X.; GILLMAN, J. D.; LEE, J. D.; ZHONG, R.; YU, O.; SHANNON, G.; ELLERSIECK, M.; NGUYEN, H. T.; SLEPER, D. A. Intricate environment-modulated genetic networks control isoflavone accumulation in soybean seeds. BMC Plant Biology, London, v. 10, n. 105, p. 1-16, 2010. http://dx.doi.org/ 10.1186/1471-2229-10-105

HEIL, C. Online reference included in article [Internet document] URL http://www.nicoletcz.cz/userfiles/file/vjecy/soybeans.pdf. Accessed 24/05/2016, 2012.

HOECK, J. A; FEHR, W. E.; MURPHY, P. A.; WELKE, G. A. Influence of Genotype and Environment on Isoflavone Contents of Soybean. Crop Science, Madison, v. 40, n. 1, p. 48-51, 2014. http://dx.doi.org/ 10.2135/cropsci2000.40148x 
JOHNSON, L. A.; WHITE, P. J.; GALLOWAY, R. Soybeans: Chemistry, production, processing and utilization. Illinois: AOCS Press, 2008.

KIM, E.; KIM S.; KIM, S.; CHUNG, I. Comparison of isoflavones and anthocyanins in soybean [Glycine max (L.) Merril] seeds of different planting dates. Journal of Agricultural and Food Chemistry, Washington, v. 60, p. 10196-10202, 2012. http://dx.doi.org/ 10.1021/jf3031259

KIM, J. K.; KIM, E. H.; PARK, I.; YU, B.; LIM, J. D.; LEE, Y.; LEE, J.; KIM, S.; CHUNG, I. Isoflavones profiling of soybean (Glycine max (L.) Merrill) germplasms and their correlations with metabolic pathways. Food Chemistry, London, v. 153, p. 258-264, 2014. https://doi.org/10.1016/j.foodchem.2013.12.066

LAURENZ, R.; TUMBALAM, P.; NAEVE, S.; THELEN, K. D. Determination of isoflavone (genistein and daidzein) concentration of soybean seed as affected by environment and management inputs. Journal of the science of food and agriculture, London, v. 97, p. 3342-3347, 2017. http://dx.doi.org/ 10.1002/jsfa.8184

LIU, K. 1999. Soybeans: chemistry, technology and utilization. New York: Chapman \& Hall, 1999.

LIU, M. M.; HUANG, Y.; WANG, J. Developing phytoestrogens for breast cancer prevention. Anti-cancer Agents in Medicinal Chemistry, Hong Kong, v. 12, p.1306 - 1313, 2012. http://dx.doi.org/ $10.2174 / 187152012803833062$

MA, W.; YUAN, L.; YU, H.; DING, B.; XI, Y.; FENG, J.; XIAO, R. Genistein as a neuroprotective antioxidant attenuates redox imbalance induced by $\beta$-amyloid peptides $25-35$ in PC12 cells. International Journal of Developmental Neuroscience, Oxford, v. 28, p. 289-295, 2010.

https://doi.org/10.1016/j.ijdevneu.2010.03.003

MORRISON, M. J.; COBER, E. R.; SALEEM, M. F.; MCLAUGHLIN, N. B.; FRÉGEAU-REID, J.; MA, B. L.; WOODROW, L. Seasonal changes in temperature and precipitation influence isoflavone concentration in short-season soybean. Field Crops Research, Aberdeenshire, v. 117, n.1, p. 113-121, 2010. https://doi.org/10.1016/j.fcr.2010.02.005

Program R Development Core Team. Vienna: R Foundation for Statistical Computing, AT, 2012

RANGEL, M. A. S.; MINUZZI, A.; BRACCINI, A. de L.; SCAPIM, C. A.; CARDOSO, P. C. Efeitos da interação genótipos $x$ ambientes no rendimento de grãos e nos teores de proteína de cultivares de soja. Acta Scientiarum. Agronomy, Maringá, v. 29, n. 3, p. 351-354, 2007.

RECKER, J. R.; BURTON, J. W.; CARDINAL, A.; MIRANDA, L. Genetic and phenotypic correlations of quantitative traits in two long-term, randomly mated soybean populations. Crop Science, Madison, v. 54, n. 3, p. 939-943, 2014. http://dx.doi.org/doi:10.2135/cropsci2013.07.0447

RODRIGUES, J. I. S; ARRUDA, K. M. A. A.; CRUZ, C. D.; PIOVESAN, N. D.; BARROS, E. G.; MOREIRA, M. A. Biometric analysis of protein and oil contents of soybean genotypes in different environments. Pesquisa Agropecuária Brasileira, Brasília, v. 49, n. 6, p. 475-482, 2014.

http://dx.doi.org/10.1590/S0100-204X2014000600009

SEIBEL, N. F.; ALVES, F. P.; OLIVEIRA, M. A.; LEITE, R. S. Brazilian soybean varieties for human use. In: SHEMY, H. A. El (Ed.). Soybean bio-active compounds. Croatia: InTech, p. 475-493, 2013.

SILVA, J.; PRUDENCIO, S.; CARRÃO-PANIZZI, M.; GREGORUT, C.; FONSECA, F.; MATTOSO, L. Study on the flavour of soybean cultivars by sensory analysis and electronic tongue. International journal of foodscience \& technology, London, v. 47, p. 1630-1638, 2012. http://dx.doi.org/ 10.1111/j.13652621.2012.03013.x 
SILVA, T. R. C.; AMARAL JÚNIOR, A. T.; GONÇALVES, L. S. A.; CANDIDO, L. S.; VITTORAZZI, C.; SCAPIM, C. A. Agronomic performance of popcorn genotypes in northern and northwestern Rio de Janeiro state. Acta Scientiarum. Agronomy, Maringá, v. 35, n. 1, p. 57-63, 2013. http://dx.doi.org/10.4025/actasciagron.v35i1.15694

USFDA - Food and drug administration. Food labeling: health claims, soy protein and coronary heart disease. Federal Register, v. 64, p. 57699 - 57733, 1999.

VILLELA, O. T.; UNÊDA-TREVISOLI, S. H.; SILVA, F. M.; BÁRBARO JUNIOR, L. S.; Di MAURO, A. O. Genetic divergence of roundup ready (RR) soybean cultivars estimated by phenotypic characteristics and molecular markers. African Journal of Biotechnology, v. 13, n. 26, p. 2613-2625, 2014.

http://dx.doi.org/10.5897/AJB2014.13661

WANG, Y.; HAN, Y.; ZHAO, X.; LI, Y.; TENG, W.; LI, D.; ZHAN, Y.; LI, W. Mapping isoflavone QTL with main, epistatic and QTL x environment effects in recombinant inbred lines of soybean. Plos One, San Francisco, v. 10, 2015. https://doi.org/10.1371/journal.pone.0118447

YU, X.; YUAN, F.; FU, X.; ZHU, D. Profiling and relationship of water-soluble sugar and protein compositions in soybean seeds. Food Chemistry, London, v. 196, p. 776-782, 2016.

https://doi.org/10.1016/j.foodchem.2015.09.092

ZHANG, J.; GE, Y.; HAN, F.; LI, B.; YAN, S.; SUN, J.; WANG, L. Isoflavone content of soybean cultivars from maturity group 0 to VI grown in northern and southern China. Journal of the American Oil Chemist's Society, Champaign, v. 91, n. 6, p. 1019-1028, 2014. http://dx.doi.org/ 10.1007/s11746-014-2440-3 